可視化情報 Vol.29 Suppl. No.2（2009年 10月）

\title{
水中での模型車両の空力実験(測定精度の改善)
}

115

友野達也 神奈川工科大学)，石綿 良三（神奈川工科大学）

\section{An Aerodynamics Examination of a Model Vehicle}

which is Submerged in a Water

(Improvement of the Measurement Precision)

Tatsuya TOMONO, Ryozo ISHIWATA

\begin{abstract}
An aerodynamics characteristic of a car affects fuel consumption, improvement of the maximum speed, run stability. An aerodynamics design for the low fuel consumption is demanded by an environmental problem and the remarkable rise of the crude oil price. In this study, The simple and easy method in search of a drag coefficient of the vehicle was developed from the run time for model vehicle which ran a slope in a water tank. Improvement of measurement precision was done by an improved device and data handling method, and it was shown that this method was effective for a shape evaluation.
\end{abstract}

Keywords : Aerodynamics characteristics, Drag, Vehicle, Model test

\section{1. 緒論}

自動車の燃料消費量の改善は，経済性はもちろんのこ と，地球環境問題および原油伍格の高騰と供給の不安定 性に関連し，その重要性は増している，そえ以外にも， 走行安定性や快適性など自動車の空力特性に関連する課 題は多く, 空力性能の優れた車体設計が求められる.

一方, 学生や一般を対象としたエコランコンテストや ソーラーカーコンテストでは, より空気抵抗の小さな車 体の開発が重要である.その開発の初期段階で，比較的 簡単な方法で車体の空力試験を行うことが有効である.

そこで著者らは水中で模型車両を走行させるという簡 便な方法で形状の評価を行うことができる空力試験方法 の開発を行った ${ }^{1}$. 本報では，測定精度の向上を図るた めの装置の改良と計測方法, デー夕処理方法の改善につ いて報告する。

\section{2. 実験装置および実験方法}

Fig.1 に実験装曡の概要を示す，水槽 (長さ $3000 \mathrm{~mm}$ ，幅 $600 \mathrm{~mm}$, 水深 $460 \mathrm{~mm}$ ) の中に斜面 (傾斜角 $\theta=8.00^{\circ}$ ，長さ $2700 \mathrm{~mm}$ ) を設置し，その斜面に沿って $1 / 10$ 模型車両を走 行させた．模型車両は開始ラインに静止させ，走行を開 始させると同時に計測を開始し，第一計測ライン $x_{1}=1000 \mathrm{~m}$, 第二計測ライン $x_{2}=2000 \mathrm{~mm}$ を通過した時間 をそれぞれ計測した。
模型車両 (Fig.2) はソーラーカーコンテスト車両を想定 したものである. 諸元を Table 1 に示す. 試験は Fig.3に 示す 3 種類のキャノピーについて行い, Type A は矩形, Type B は丸型, Type C は雨滴形とした.

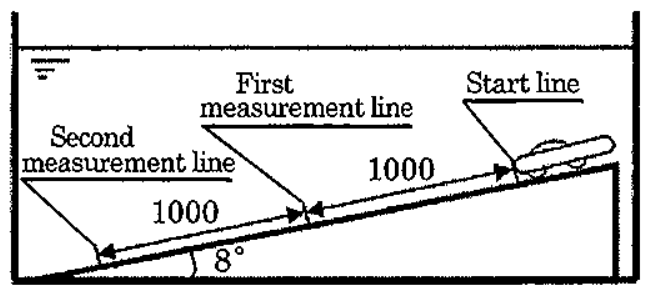

Fig.1 Experimental apparatus (unit: $\mathrm{mm}$ ).

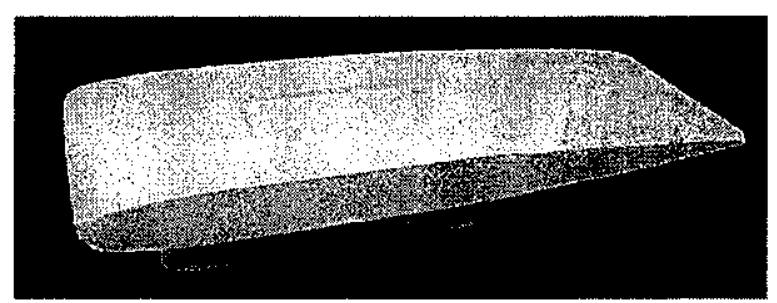

Fig.2 Test model(canopyless).

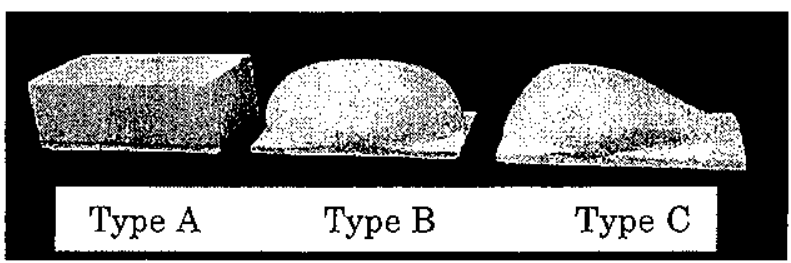

Fig.3 Test canopy. 


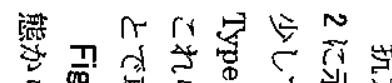

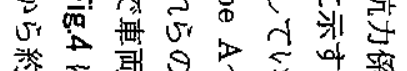
- T 9 貉

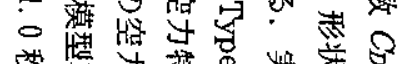

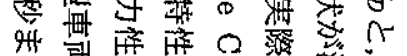

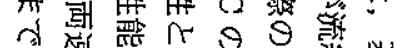

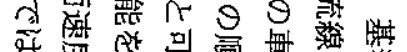

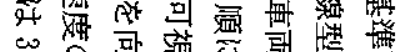

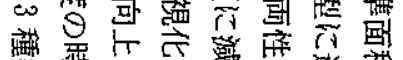

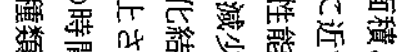

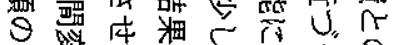

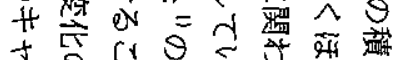

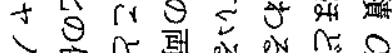

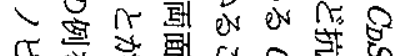

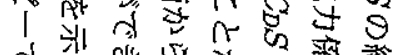
त्र

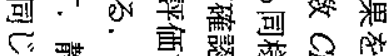

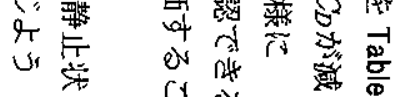
要 $\theta$ 而

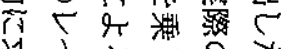
$\frac{1}{*} \rightarrow$ ev

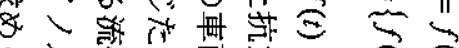

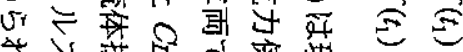

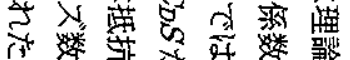
诲 $\theta$ 正

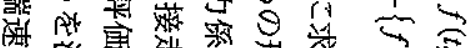

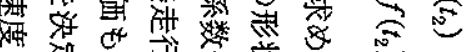

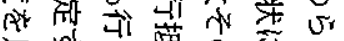
丑 of $v$ 整 9 \%

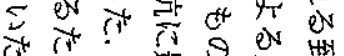

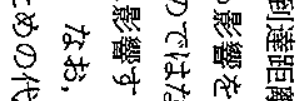

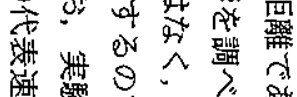

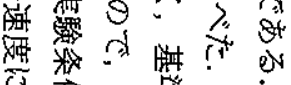

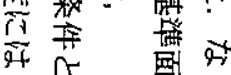

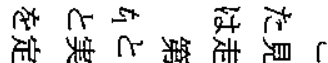

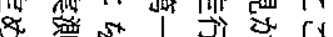

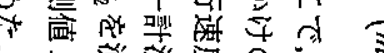

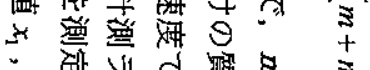
许 v1 姃

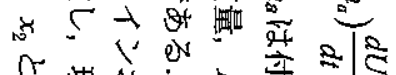

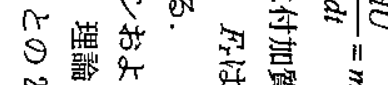

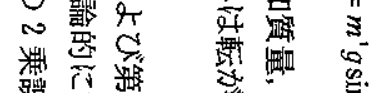

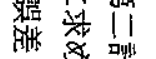

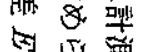

vir 縵

瓶 到

些

के

比望罝

\% 需

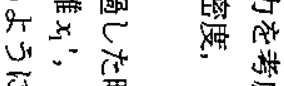

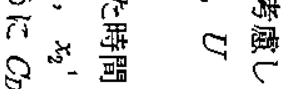

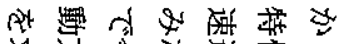

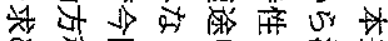

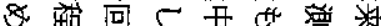

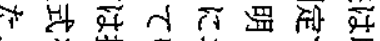

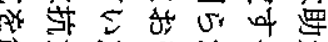

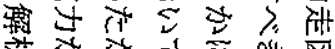

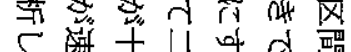

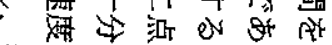

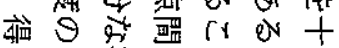

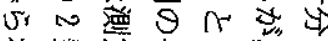

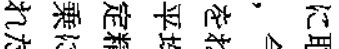

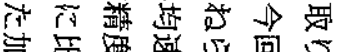

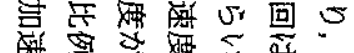

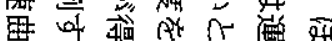

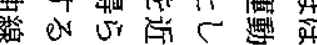

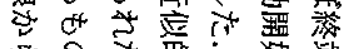

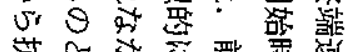

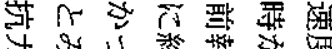

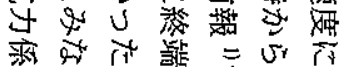

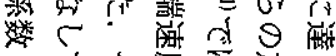

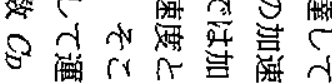

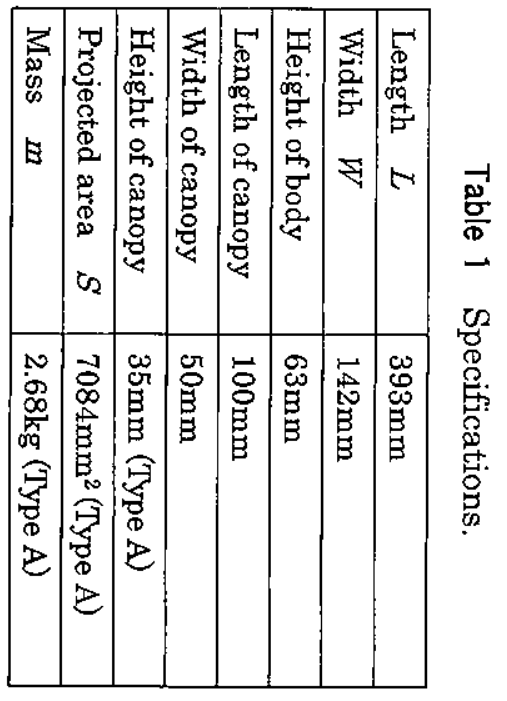

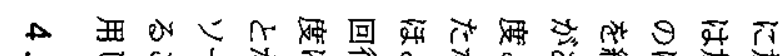

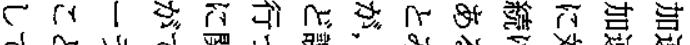

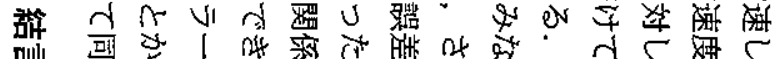

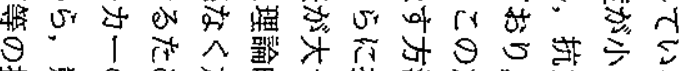

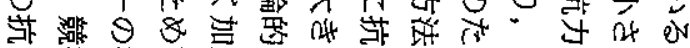

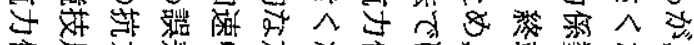

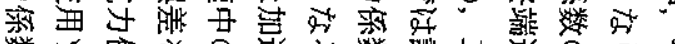

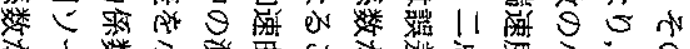

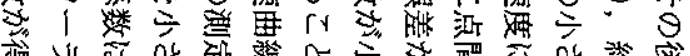
留 UI

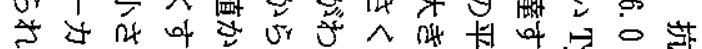

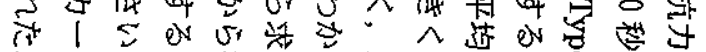
स $\mathrm{dr}^{\circ}$ ir

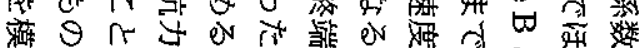

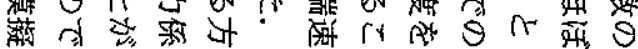

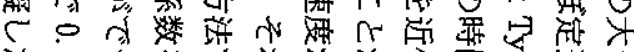

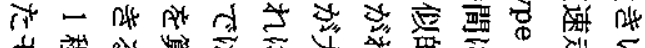

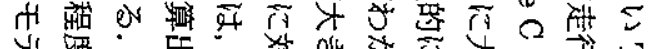

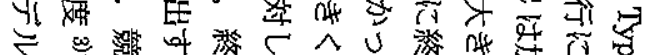

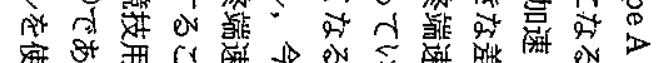

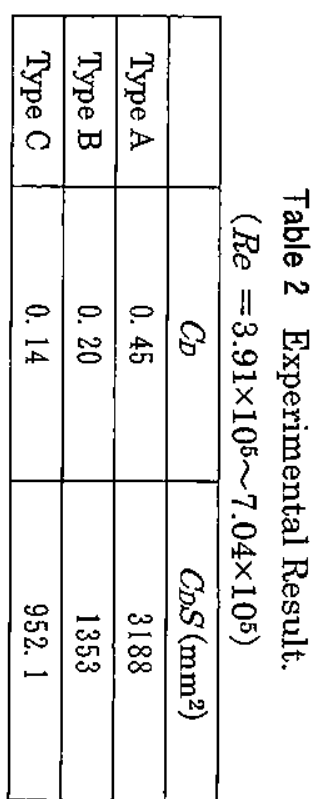

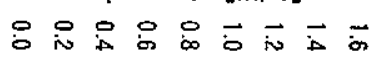

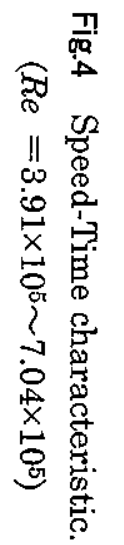

\section{뭉}

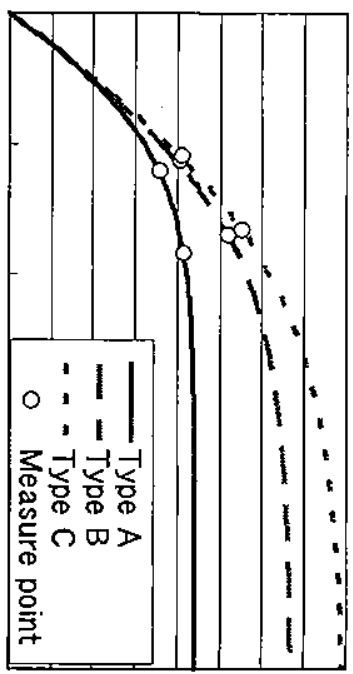

